\title{
Heather Hirschfeld. The End of Satisfaction: Drama and Repentance in the Age of Shakespeare. Ithaca, NY: Cornell University Press, 2014. Pp 239.
}

KENNETH J.E. GRAHAM

University of Waterloo
Early Theatre 19.1 (2016), 175-8

http://dx.doi.org/10.12745/et.19.1.2904

The relationship between religious change and the early modern theatre continues to prove fertile critical ground in Heather Hirschfeld's book, which follows Sarah Beckwith's Shakespeare and the Grammar of Forgiveness (2011) in exploring the consequences for drama of the Protestant rethinking of repentance. Of the two, Hirschfeld's is by far the darker book - as Hirschfeld says, 'I treat the plays as less recuperative in their sensibilities than Beckwith does' (14) - a consequence of a shift in focus from forgiveness to satisfaction, and from romance to tragedy. But like Beckwith's, Hirschfeld's is an insightful book that repays close attention.

Hirschfeld begins with two chapters on the theory and history of satisfaction. The introduction distinguishes two aspects of satisfaction, the third part of the Roman Catholic sacrament of penance. On the one hand, there is 'econo-juridical satisfaction' (5), a 'principle of commensuration' (3) arising from the need to calculate whether one had 'done enough' to compensate for sin. On the other, there is appetitive satisfaction, 'a synonym for the simple ... fulfillment of needs and wants' (3). Part of Hirschfeld's argument is that the sacramental model held the two together. But the Reformation attacked Catholic understandings of the first, contending that, like good works in general, satisfaction had no power to effect salvation. Hirschfeld argues that the resulting shock waves were felt not only in theology and penitential practice but in other fields where satisfaction played a role.

Chapter 1 reviews the history of penance with special attention to satisfaction. Roman Catholics struggled to define the amount individuals needed to do in order to pay for their sins, but never doubted the possibility of such payment. But for Protestants 'the problem of enough' was its impossibility: the belief in total depravity and the doctrine of justification by faith meant that individuals could do nothing to repay God, and to believe otherwise was to succumb to the temptations of a religion of works. In practice, however, Protestants emphasized the pain and sorrow of contrition, where an affective 'enough' tended to slide into excess.

Chapter 2 explores fault lines in understandings of Christ's own satisfaction through a reading of Doctor Faustus as 'a contorted harrowing of hell play' (40). As hell was 'the culture's most aggressively imagined experience of the promise and impossibility of punitive satisfaction' (42), so the harrowing of hell was a 
'model of Christian triumph' (62). But the validity of this model was challenged by Protestants who increasingly attacked the literal descent to hell as superfluous, since the crucifixion had fully satisfied God's justice. The debate about Christ's descent to hell therefore 'extends the problem of human satisfaction ... to Christ' (54). Against this backdrop, Hirschfeld understands Faustus as adding 'a special fantasy of Christological imitation' (43) to the dramatic tradition: he, too, wishes to harrow hell. But instead of descending, Faustus conjures souls from hell, and his conjuring 'comes to look like a pale version of Christ's release of righteous souls from the underworld' (57). Ultimately, satisfaction of all kinds eludes Faustus: his appetitive dissatisfaction is 'a corollary to what he senses as his inability to make satisfaction penitentially' (55), and his despair reflects contemporary uncertainties about Christ's own expiatory satisfaction: how it works, and how sinners might gain access to it.

The remaining chapters take up revenge, economics, and marriage. Chapter 3 argues that 'Revenge and repentance, as responses to wrong-doing, are structurally analogous pursuits' (66). Hirschfeld unearths a tendency in the period to refer to the self-punishment of contrition as revenge, while arguing that, conversely, revenge sometimes served as a form of self-punishment. 'Elizabethan revenge tragedy's great theological and theatrical contribution to the dramatic tradition', she contends, was 'to accommodate the contemporary theological suspicion about doing and feeling enough in the punishment of an offending self to the classical Senecan impossibility of doing and feeling enough in the punishment of an offending other' (75). She pursues this thesis through The Spanish Tragedy, Hamlet, and The Revenger's Tragedy. 'Hieronimo's explicit revenge stratagems on Lorenzo and Balthazar ... start to look like Hieronimo's penitential revenge on himself' (76). Hamlet doesn't kill the praying Claudius because Claudius's apparent penitential satisfaction means retaliatory dissatisfaction to Hamlet, who can find satisfaction neither through penance nor through revenge. Vindice parodies and perverts the confessional process, using it not to make penitential satisfaction to those he has injured but in an attempt to increase the satisfaction he gains from his revenge. In general, Hirschfeld finds a 'terrible irony embedded in the structure of revenge, whose promise of restitution and equivalence can only be accomplished through amplified, excessive punishment and pain' (136).

Chapter 4 considers the relationship between economics and penitential exchange. Hirschfeld charts a tension between an economic morality that emphasized the virtue of 'enough' and a Protestant theology that attacked the same idea in penitential contexts. She follows this tension through William Wager's 
Enough Is as Good as a Feast and into The Merchant of Venice. Wager shows the difficulty of being content with enough, illustrating Hirschfeld's large claim about the form his play represents: 'The late medieval morality play depended upon the possibility that its characters could atone for their misdeeds and sins; the Tudor homiletic drama depends upon the assumption that its characters cannot' (103). In Merchant, the theological separation of abundant grace from penitential satisfaction supplies a logic that is played out largely at the economic and legal level of the play. Shylock's bond, representing 'the principle of calculation and proportionate adequation that marks the lost penitential satisfactory' (111), falls victim to the Christians' plenty. As legal authority, Portia must 'sever the relationship between gratuitous mercy and the adequations of the law, between plenty and enough' (115). The play, Hirschfeld ends by suggesting, 'can be read as an allegory of the Protestant dismantling of the sacrament of penance and the place of satis within it' (118), but it is an ironic one that 'exposes not only the conditionality of supposedly unconditional mercy but also the lingering attraction and reliance on the economies of satisfaction in the face of their disavowal' (118).

The final chapter posits 'a special connection between marriage and repentance' (123), both of which had lost their sacramental status but were still seen as redemptive. In addition, marriage presented an occasion for sin, and could be repented in toto if one made a poor choice. The focus of the chapter is on the last of these connections, beginning with a reading of Othello as a play about repented marriage. Hirschfeld argues against readings of satisfaction in the play as appetitive and epistemological; such readings 'do not ... recognize the profound confluence between the possibilities of sexual and penitential satisfaction' (135). Othello initially appears satisfied, but repents his marriage when Iago persuades him that Desdemona has already repented hers. The murder of Desdemona attempts 'to reestablish Othello in a world in which precise atonement ... is possible' (136-7). But 'Protestant revaluations of penitential efficacy' (138) finally dominate the play, and in Shakespeare's domestic tragedy as elsewhere there is no satisfaction to be found. The chapter ends with a reading of Beaumont and Fletcher's Love's Pilgrimage, which both mocks the idea of satisfaction and betrays 'a lingering fascination with ... the possibility of satisfaction in penitential and marital economies' (140).

This is a painstakingly historicist book, attentive to both continuities and breaks with the medieval past. Much of its energy is directed at tracing conceptual and affective parallels across numerous cultural discourses. Hirschfeld rejects reading such discourses as simply analogous or homologous. Instead she places religion first among cultural equals: repentance 'needs to be seen as organizing 
or intervening directly in other forms of exchange' (11). Her efforts to treat repentance as a master discourse find, I think, varying degrees of success. I'm not entirely convinced by the arguments linking marriage to repentance, and the repented marriage doesn't seem a distinctively Protestant phenomenon. On the other hand, the connections between economics and the calculations of satisfaction seem rich and suggestive.

Perhaps because most of the plays she considers are tragic, Hirschfeld's argument presents a version of the subtraction theory of the Reformation: Protestantism ended penitential satisfaction but not its 'residual allures' (3) or 'lingering appeal' (38), creating a tragic void where attempts to find satisfaction were doomed to fail. Hirschfeld pays relatively little attention to Protestant alternatives to penance. For example, although she identifies assurance as the affective replacement for satisfaction (17) and acknowledges the role of the church courts in 'making satisfaction to others' (150) - a surprising revelation at the end of a book dedicated to the proposition that the Reformation ended satisfaction - neither is a factor in her analysis. A study of romances - in which genre Beckwith uncovers the forms that forgiveness took after the Reformation — or comedies might lead to very different conclusions. Nevertheless, Hirschfeld's readings are consistently imaginative and challenging. Her book is the product of wide reading and deep and sustained thinking, and does enough to satisfy this reader. 